\title{
Views of Preservice Primary School Teachers' on Inclusion and Differentiated Science Experiments
}

\author{
Hatice Mertoğlu ${ }^{1}$ \\ ${ }^{1}$ Science Education Department, Marmara University, Istanbul, Turkey \\ Correspondence: Hatice Mertoğlu, Science Education Department, Marmara University, Istanbul, Turkey. \\ E-mail: hatice.mertoglu@marmara.edu.tr
}

Received: February 26, 2020 Accepted: April 1, 2020 Online Published: April 4, 2020

doi:10.5539/jel.v9n3p47 URL: https://doi.org/10.5539/jel.v9n3p47

\begin{abstract}
Today, individuals with special needs who are reported to increase each day are receiving education with their peers in general classes and are subjected to inclusive practices according to the developments in the field of special education and legal regulations. However, it is also reported that there are problems with special education in many countries. The goal of this study is to reveal the views of pre-service primary school teachers on inclusive education and science laboratory lesson taught with differentiated approach and contribute to the solution of problems in inclusive education to some extent. Study sample comprise 103 pre-service primary school teachers studying at the 2nd grade of a state university in İstanbul in 2017-2018 academic period. Quantitative data of the study carried out with pretest-post test control group random quasi-experimental pattern were published by Mertoğlu, Topçu in 2020 and only qualitative data are used in this study. Condition of inclusive students in the experiment group was mentioned only as an individual difference and science laboratory lesson was taught with differentiated approach for one term. Students in the control group took the science laboratory class according to the normal program. Data obtained with lesson evaluation form, inclusion question form and field notes were evaluated and interpreted with descriptive data analysis method. Research results show that students in both control and experiment group need to take training on inclusive education. It was found that students in experiment group gained an awareness of instructional adaptations while the views of students in control group about instructional adaptations were far from being relevant to inclusive education. Views of students in experiment group show that science lessons taught with differentiated approach contributed to them "to remove their prejudices against science, to learn and teach science", "remove their prejudices against students with special needs", "remove their feelings, attitudes and worries about inclusion" and "realize inclusive practices in science education when they become teachers".
\end{abstract}

Keywords: differentiated science experiments, inclusion, science education

\section{Introduction}

Literature review reveals that the right of individuals to education has been recognized as the most basic right with national and international legal regulations and secured under law. Still, it is reported that there are problems in inclusive education and inclusive practices are not effectively brought to life in many European countries (Yılmaz \& Melekoğlu, 2018) and Turkey (Yılmaz \& Melekoğlu, 2018; ERG, 2011).

The first attempts to give education to individuals with special needs in special education classes or special education schools occurred in the 16th century. However, these special education practices were often criticized for hampering social adaptation of students with special needs by separating them from their peers, not contributing to academic achievement sufficiently and placement of unqualified students in these classes. With the developments in the fields of special education and human rights in 1960s, a notion of educating students with special needs in the same schools and classes with their peers occurred and inclusive practices turned into a norm (ERG, 2011; Batu \& Kircaali-İftar, 2016). Students began to receive education with their peers in general classes in Italy 1971, England in 1974, France and the U.S.A in 1975, Norway in 1976 as a result of legal regulations. Inclusive practices in Turkey were legalized with the "Law on Children with Special Needs" that came into force in 1983. Inclusive education aims to strengthen social skills and social recognition of students with special needs through interaction with their peers and make them active members of their classes (ERG, 2011). 
Inclusion is defined as education of students with special needs with their peers in general classes on condition that these students and class teachers receive special education services (Kırcaali-İftar, 1998; MEB, 2017). Many researches on the effectiveness of inclusive practices show that individuals with special needs who receive education with their peers join the community more actively and find more ways of improving their life quality (Sucuoğlu, 2004; ERG, 2011). Inclusion offers opportunities for responding to the requirements of not only students with special needs but also normally developing children and making all students use their capacity (Atkın, 2013; Özgür, 2015).

In addition to legal regulations, successful implementation of inclusive education requires several precautions to include students with special needs in general education classes. Training and teaching relevant skills to teachers is important for implementation of inclusive education at schools successfully. Lesson programs must be amended, adapted and differentiated according to the requirements of students with special needs (ERG, 2011; Kargin, 2004; MEB, 2015).

Teachers have a significant role in the success of inclusive practices as it is their duty to plan and implement education programs of students and enable their academic and social development (ERG, 2011; Özgür, 2015). Therefore, differentiation of instruction programs and instruction by teachers according to the needs of students will contribute significantly to the success of inclusive practices.

Differences of student in a differentiated classroom become significant components of teaching and learning. A differentiated classroom provides students different ways of accessing content, giving meaning to concepts and developing products in order to learn effectively. A teacher in a differentiated classroom recognizes that different students have different needs, plans and adapts instruction to different needs of students. Teachers are concerned with at least three aspects of curriculum: (1) content-input (what students learn); (2) process (how students keep on giving meaning to ideas and knowledge) and (3) product-output (how students display what they have learned). By differentiating these three aspects, teachers offer different approaches to what students learn, how they learn and how they display what they have learned (Tomlinson, 2001).

Learning process is often designed for students with moderate cognitive skills in instruction programs.As a result of these practices designed according to this program, students with poor cognitive skills may fail and potential of gifted students may not be properly used or even neglected (Avcı \& Yüksel, 2014). However, individual differences must be considered while designing instruction programs and they must address all the students. Thus, all students are able to learn at their own paces and depth of knowledge as instruction is planned according to the individual differences of students in differentiated approach. Differentiated instruction is based on many approaches such as social structuralism, brain-based learning etc. Differentiated instruction seeks for different ways of learning for different students considering learning styles, multiple intelligence and sociocultural features (Avc1 \& Yüksel, 2014). It might be considered that students with special needs who are inclusive education students can be dealt with in the context of these different students.

There are not many studies in literature dealing with major course needs of students with special needs and responding to those needs. Most of the studies are the ones that focus on hearing-impaired and visually impaired individuals (Okçu \& Zorluoğlu, 2019). Science is one of the most important lessons for all students including those with special needs as it involves knowledge and skills necessary for daily life. Therefore, adaptation and differentiation of instruction programs according to the individual differences of each student will help them to learns science and succeed at science (Okçu \& Zorluoğlu, 2019). On the other hand, Özmen (2012) reports that teachers do not differentiate instruction according to the needs of students with special needs in their classrooms. Therefore, a teacher who has a student with special needs must be able to do instructional adaptations and differentiate teaching content. These adaptations must also take into account the individual differences of all students and must respond to their needs. In this context, science laboratory lessons in this study were taught with differentiated approach in order to attract attention of teacher candidates to individual differences and create an awareness of inclusive education by differentiating experiments.

The goal of this study is to reveal the views of pre-service primary school teachers on inclusive education and science laboratory lesson taught with differentiated approach and contribute to the solution of problems in inclusive education to some extent. Answers to the following questions were sought for this purpose.

What are the shortcomings and needs of pre-service primary school teachers related to inclusive education?

What are the views of pre-service primary school teachers on instructional adaptations that might be done in science lessons?

What are the views of pre-service primary school teachers on science laboratory lessons taught with 


\section{differentiated approach?}

\section{Method}

\subsection{Research Model}

Quantitative data of the study carried out with pretest-post test control group random quasi-experimental pattern were published by Mertoğlu, Topçu in 2020. According to this pattern, two groups are established from sample group by random sampling, one control group and one experiment group. Members of the groups are subjected to measurement in terms of their relation to dependent variables before implementation while experiment group is subjected during the implementation phase to the experimental process the effect of which is to be tested. Then, the same data collection tools are used to measure the relation of the sample with dependent variable (Büyüköztürk, Kılıç Çakmak, Akgün, Karadeniz, \& Demirel, 2016). Only qualitative data were used in this study. In the study, shortcomings and needs of teacher candidates related to inclusive education were identified and their views on science lessons taught with differentiated approach were determined and interpreted.

\subsection{Research Group}

Study sample comprise 103 pre-service primary school teachers studying at the 2nd grade of a state university in İstanbul in 2017-2018 academic period. Teacher candidates reported that they had not taken any training on inclusive education before and took part in the study on voluntary basis.

There are 2 study groups, one experiment and one control. These groups were assigned with simple random sampling method. In this sampling method, groups are assigned randomly by giving equal probability of being selected to each sampling unit (Büyüköztürk et al., 2016). 53 teacher candidates were placed in control group and 50 teacher candidates in experiment group as a result of random sampling.

\subsection{Data Collection Tools}

Study data were collected by means of lesson evaluation form, inclusion question form and fiedl notes of the researcher.

\section{Lesson evaluation form}

Experiment group was presented a lesson evaluation form consisting of 3 open-ended questions and asked to evaluate the lesson in order to analyse their views on the lesson taught with differentiated approach. Questions in this form are: 1) "Evaluate the differentiated science laboratory lesson in the context of inclusive education", 2) "Evaluate the differentiated science laboratory lesson in the context of your views on inclusive education students", 3) "Evaluate the differentiated science laboratory lesson in the context of science teaching".

\section{Inclusion question form}

Inclusion question form was presented to students both in experiment and control group in order to identify their views on their shortcomings and needs related to inclusive education. Questions in inclusion question form are: "1) What are your shortcomings and needs related to inclusive education?", "2) How would you do the science experiments if you ha d student with special needs in your class?"

\section{Implementation}

Science laboratory lesson was given with differentiated approach for one term to the teacher candidates in experiment group of the study. On the other hand, control group was not subjected to any intervention and they took the lessons and did the experiments according to the program. This is a course given in the 4 th term of class teaching department, where 1 hour is spared for theory and 2 hours for practice. Lesson content includes the role and purpose of laboratory in science teaching, structural approach and laboratory practices, types of experiment, experiments designed for primary school (planning, implementation and evaluation of experiments).

The researcher gave the lesson with differentiated approach for one term, dealing with the condition of students with special needs as an individual difference in an attempt to create an awareness before giving inclusive education. He mentioned students with special needs in general terms, attracting attention to and giving examples of adaptations that might be done for students who have visual impairment and slight mental disability. Thu, the researcher covered the eyes of a student with sleeping mask, gave the lesson with no adaptation for him and finally asked the student to explain what he felt. Then he included the student in the lesson and repeated the lesson, asked again what he felt and created a discussion atmosphere in the classroom. Thus, the researcher presented an example of how to differentiate a science lesson in case there was a student with special needs in the class. Experiments were carried out by the researcher in the form of demonstration, animation and individual experiments in other lessons until the mid-term exams according to the different learning styles and individual 
differences of students. After the mid-term exams, students were asked to do group experiments according to their individual differences. The researcher also created a class discussion and took notes by asking students how they would do the same experiment if they had a student with special needs in their class.

Lesson evaluation form was presented to students in experiment group while inclusion question form was presented to the control group at the end of the term.

\subsection{Data Analysis}

Descriptive and content analysis approaches were used for data analysis of the study. Questions in the lesson evaluation form were evaluated with descriptive analysis and questions in the inclusion question form were evaluated with content analysis.

According to Yıldırım and Şimşek (2013), qualitative data analysis might be studied in 2 groups; descriptive analysis and content analysis. Descriptive analysis is more superficial than content analysis and rather used in studies where conceptual structure of the research is clearly predefined. In this approach, data obtained are summarized and interpreted according to predefined themes. Descriptive analysis often gives place to quotations in order to reflect the views of individuals remarkably. The goal of this analysis type is to present the findings to the reader in an organized and summarized way. On the other hand, similar data are categorized in the context of specific concepts and themes, organized and summarized understandably in content analysis (Yıldırım \& Şimşek, 2013).

Descriptive data were transformed into themes and hypotheses were established by selecting and combining those that have $80 \%$ repetition rate in the coded list coded by open-coding. Two experts calculated the frequency (f) of codes and themes derived from data obtained from the views of science teachers on the homework by means of content analysis. Data reliability was tested with [Consensus/ (Consensus + Disagreement)] x 100 formula suggested by Miles and Huberman (1994). Fit index of coding in this study was found $85 \%$ by using this formula. According to Yıldırım and Şimşek (2013), reliability percentage is achieved when the fit index in reliability test is $70 \%$. Therefore, these results show that coding reliability of the researchers is sufficient.

\section{Results}

\subsection{Findings on the First Sub-Problem}

Responses given by students when they were asked the first sub-problem of the study "What are your shortcomings and needs related to inclusive education?" are presented on Tables 1 and 2.

Table 1. Shortcomings and needs of experiment group students related to inclusive education

\begin{tabular}{lllll}
\hline & Pre-test & \multicolumn{3}{c}{ Post-test } \\
\cline { 2 - 5 } Types of knowledge & $\mathbf{N}$ & $\mathbf{\%}$ & $\mathbf{N}$ & $\mathbf{\%}$ \\
\hline Training & 31 & 62 & 30 & 60 \\
Experience & 3 & 6 & 19 & 38 \\
Patience & 1 & 2 & - & - \\
Simplification & 3 & 6 & 1 & 2 \\
No idea & 12 & 24 & - & - \\
Total & 50 & 100 & 50 & 100 \\
\hline
\end{tabular}

Table 1 shows that responses most given by students in pre-test form were "receiving training" and "I have no idea". It is see that the number of students who left the question unanswered dropped and the number of students who responded with "gaining experience" increased after the implementation process. This shows that students need to gain experience and interact with students with special needs beside receiving training. Below are given some examples of students' views against this question:

"I have no experience, being together and interacting with them are my shortcomings and what I need"(K14).

"I wonder about practices in the classroom setting" (K9).

"Lack of practice is my shortcoming even if I hale learned it theoretically" (K35).

As can be understood from the quotations, students need practical training in order to learn how to treat students with special needs. They also wish to receive training and interact with them in order to respond to their needs. Below are given examples of students' views on this issue: 
"For example, I need sign language if I have a hearing-impaired student. I have to develop myself to meet the requirements of students with special needs" (K45).

"As I have not found an opportunity to interact with such individuals, I do not know what they feel and what problems they go through" (K32).

Table 2. Shortcomings and needs of control group students related to inclusive education

\begin{tabular}{lllll}
\hline & Pre-test & \multicolumn{3}{c}{ Post-test } \\
\cline { 2 - 5 } Types of knowledge & N & \% & N & \% \\
\hline Training & 26 & 49 & 40 & 75 \\
Experience & 8 & 15 & 7 & 13 \\
Material & 1 & 2 & - & - \\
No idea & 18 & 34 & 6 & 12 \\
Total & 53 & 100 & 53 & 100 \\
\hline
\end{tabular}

Table 2 shows that students responded mostly "receiving training" and "I have no idea" in pre-test form. However, the number of students who left the question unanswered dropped and the number of students who said "receiving training" increased in final evaluation. Below are given examples of teacher candidates' views on this issue:

"I do not know my shortcomings and needs as I have never received training on this issue" (K50).

"I have not given education to a student with special needs, I want to experience it, I want to receive training and know about this issue" (K24).

As can be understood from the quotations above,teacher candidates do not know about their shortcomings and needs as they have not received such a training. It is also apparent that they have several fears and worries about student with special needs. Below are given some examples of their views:

"it is very hard to give special education" (K28).

"I avoid when I see students with special needs." (K34).

\subsection{Findings on the Second Sub-Problem}

Responses given by students to the second sub-question of the study "How would you do the science experiments if you had a student special needs in your class?" are presented on Tables 3 and 4:

Table 3. Views of control group teacher candidates on adapting science experiments

\begin{tabular}{|c|c|c|}
\hline Types of Knowledge & $\mathrm{N}$ & $\%$ \\
\hline Instructing them like instructing other students, doing no differentiation & 35 & 37 \\
\hline Treating inclusive students differently, taking special care of them keeping them under supervision & 27 & 28 \\
\hline Giving inclusive tasks to include them in the experiment & 18 & 19 \\
\hline Explaining the experiment slowly & 15 & 16 \\
\hline Total & 95 & 100 \\
\hline
\end{tabular}

Table 3 show that the most common view of control group students on inclusive students was instructing them like other students and doing no differentiation. It is followed by treating inclusive students differently. It is seen that these teacher candidate views are far from being relevant to inclusive education and instructional adaptations. 
Table 4. Views of experiment group teacher candidates on adapting science experiments

\begin{tabular}{lll}
\hline Types of Knowledge & $\mathrm{N}$ & $\%$ \\
\hline Activating inclusive students including them in the lesson, experiment with the whole class, giving & 82 & 23 \\
experiment-related tasks, socializing & & 9 \\
Using reinforcer, rewarding success & 30 & 8 \\
Teaching by play & 28 & 19 \\
Considering different learning styles of students, using different methods and techniques & 67 & 7 \\
Making them taste success, strengthening their self-confidence & 25 & 20 \\
Adapting the subject to the level of inclusive students & 70 & 14 \\
Making them sit in front rows & 48 & 100 \\
Total & 350 & \\
\hline
\end{tabular}

Table 4 above shows that responses most given by experiment group students are including the whole class in the lesson, experiment etc. Rather than inclusive students and adapting the subject to the level of inclusive students. They also responded by saying that that they would include the inclusive student in the lesson with no discrimination from others, make them sit in front rows, do instructional adaptations according to the level of inclusive students.

\subsection{Findings on the Third Sub-Problem}

Views of teacher candidates on differentiated science experiments derived from lesson evaluation form data were analysed under 4 themes; helping students "to remove their prejudices against science, to learn and teach science", "remove their prejudices against students with special needs", "remove their feelings, attitudes and worries about inclusion" and "realize inclusive practices in science education when they become teachers".

\subsubsection{Helping Them to Remove Their Prejudices Against Science, Learn and Teach Science}

\section{Differentiated science experiments contributed to teacher candidates in removing their prejudices against science, learning and teaching science.}

Teacher candidates reported that they had several opinion, views on the difficulty of science lessons before this implementation process at the beginning of the term. However, they reported after the implementation process that they learned science subjects more easily and enjoyably by doing and learning through different methods and techniques, which strengthened their self-confidence.

"... I came to realize that science subjects which seemed hard to understand could be grasped more easily" (K3).

"I understood that I could both learn and teach science to students with special needs no matter how hard they say it is. This lesson broke my prejudices on the difficulty of science lessons" (K21).

"I became more self-confident. Now I understand that the only barriers are the ones in our minds" (K35).

“... group work was a good experience for us. We agreed that we could make these subjects more fun, engaging and easy to understand" (K44).

Teacher candidates also said that they learned how to teach science subjects and that added to their self-confidence. They reported that they gained experience by creating awareness of students with special needs. They added that they found an opportunity to learn how to include inclusive students in the lesson by simplifying and materialising science subjects.

\subsubsection{To Remove Their Prejudices Against Students with Special Needs}

\section{Differentiated science experiments helped teacher candidates to remove their prejudices against students with special needs and improve their views and feelings.}

It was observed that most teacher candidates initially had negative views of students with special needs and even were afraid of them and thought they should not receive education in the same environment with normal children. Some even reported that they had never imagined having s student with special needs in their classroom. Students were worried about students with special needs and instructing them. However, they stated that their opinions totally changed after taking the lesson and they adopted inclusion, which helped them to remove their worries and fears in this issue.

"most of us were afraid of students with special needs but now we have overcome it. We also have realized that there is nothing a person cannot do if he wants even if he is physically or mentally disabled" (K40). 
"I did not think that I would have a student with special needs. I did not know how to teach even if I had one. To be honest, I had fears." (K9).

"Before this lesson, I thought that a student who cannot see would fail. After the lesson, I began to think that there was actually no difference between us and small adaptations might help all students "including those with special needs" to join the lesson actively" (K24).

"My prejudices against children with special needs have been broken" (K47).

"I used to think that students with special needs might receive education at special education centres. It is different because I think that they must be with other children" (K28).

"I have come to realize that they can receive education in the same class with everyone else" (K44).

As can be understood from quotations above, teacher candidates were able to get rid of their prejudices against students with special needs.

\subsubsection{To Remove Their Feelings, Attitudes and Worries of Inclusion}

\section{Differentiated science lessons helped teacher candidates to remove their feelings, attitudes and worries of inclusive education.}

Teacher candidates reported that they realized how they could integrate children with special needs into the society by sparing a little more time for them than others and caring them more. They understood that it was possible with the help of experiments and did not require too much effort.

"I was aware of this issue but I did not know what to do if I had such a student and that worried me a lot" (K46).

"I understood how wrong and shameful it was for me to think that individuals with any disability had to study at their own schools and how bad it was to exclude individuals who were actually not different from us" (K33).

"We had not even imagined having a student with special needs in our classroom. We thought that we would not be able to give education even if we had one and were worried about it. Thanks to this lesson, we have practically learned that it is not right to exclude children with special needs and they could receive ducation in the same classroom with their peers to the possible extent" (K37).

"I am sorry to say that I was not aware of how to approach a student with special needs and meeting such a child used to frighten me. My opinions and point of view has changed so that I now think nothing is impossible" (K38).

\subsubsection{To Realize Inclusive Practices in Science Education When They Become Teachers}

\section{Differentiated science experiments have contributed to teacher candidates in the context of doing exclusive practices in science education when they become teachers.}

Differentiated science experiments turned out to be quite useful for teacher candidates in the context of realizing inclusive practices in science education when they become teachers. Examples of student views presented below support this idea:

"On the first day of the lesson I thought that lesson content would only include science and did not imagine that it would deal with students with special needs who would actually be an important of my job in a few years" (K26).

"I have believed that small touches would result in big changes. I will always try to practice it in my job" (K4).

"Experiments in this lesson will contribute significantly to my teaching life and instruction in the future" (K27).

"I have found an opportunity to answer the question what I could do if I had a student with special needs" (K17).

It was found that this lesson helped teacher candidates to gain knowledge of adaptations for students with special needs and adopt inclusive education. Below are presented examples of teacher candidates' views on this issue:

"Thanks to this lesson, I have learned how to include a student with special needs in the lesson and make changes in instruction. I have adopted the principle of changing the experiments according to the disabllity of the student. This lesson has encouraged us to care about students with special needs" (K21). 
"I have learned about instructional adaptations that might be done" (K31).

The fact that teacher candidates refer to adaptations for not only students with special needs but also the whole class shows that they have understood the philosophy of inclusive education. Students' view presented below support this idea:

"I believe more than ever that I can teach the lesson to every student. I have begun producing new ideas of instructing with the awareness I have gained. I believe that students with special needs can receive education in normal classes" (K25).

"I will do my best not to deprive any student of the right to learn" (K25).

"We had never taken such a course before. We have understood with this course that every student is unique and has a different perception level" (K42).

Quotations below support the fact that teacher candidates have adopted inclusive education. They reported that instructional adaptations that they implemented in group work helped them to create an awareness of how to teach science subjects and find an opportunity for science teaching.

\section{Discussion}

There are many important factors for the success of inclusive education. The most important of these factors is probably the teacher who implements the program. Creation of an effective learning environment by the teacher in the classroom is as important as his positive attitude towards inclusive education. Differentiation of instruction is inevitable in a classroom where there are individual differences. In this context, science laboratory lessons were taught with differentiated approach in order to prepare teacher candidates for inclusive education and provide a model for researchers who will study this issue in the future. Therefore, the goal of this study is to identify the views of students on differentiated science experiments and contribute to inclusive practices.

Views of pre-service primary school teachers were identified and hypotheses were established in the study. Study results indicate that science lessons taught with differentiated approach have contributed to teacher candidates in the context of science education. According to teacher candidates, these lessons have helped them to:

- Remove their prejudices against science, learn and teach science

- Remove their prejudices against students with special needs,

- Remove their feelings, attitudes and worries about inclusion

- Realize inclusive practices in science teaching when they become teachers.

This research has concluded that differentiated science experiments have helped teacher candidates to remove their prejudices against students with special needs and improve their views and opinions about inclusive education. These results obtained in the study overlap with previous studies in literature. One of the most significant factors in the success of inclusive practices is the teacher. Studies (Avramidis \& Norwich, 2002; Batu, 2000; Forlin, 2001; Sharma, Forlin, Loreman, \& Earle, 2007; Kurcaali-İftar, 1998) show that positive attitudes of teachers against inclusive education positively influence the success of inclusive program. It is also reported that teachers who have positive views on this issue use instructional strategies that are useful for all students in the classroom (Bender, Vail, \& Scott, 1995). Salar and Turgut (2019) studied how differentiated instruction influenced the classroom atmosphere. It was reported at the end of the study that it had positive influence on teacher-student and student-student relationships, encouraged students to engage with the lesson and provides equality, justice in the learning environment. A study by Yabaş and Altun (2009) shows that differentiated instruction has an influence on maths achievement, meta-cognitive skills and self-efficacy perception of students. Researches draw attention to the fact that differentiated instruction gives every student a chance to be successful no matter what their individual features are. After a review of studies dealing with the issue, it might be suggested that differentiated approach used in this study will help teacher candidates to realize inclusive practices in science education.

Several studies in literature show that taking a training in inclusion influences the attitudes of teacher candidates (Alsheikh \& Elhoweris, 2006; Altıntaş \& Şengül, 2014; Bek, Gülveren, \& Baser, 2009; Gözün \& Yıkmış, 2004; Orel, Töret, \& Zerey, 2004). Here, the result of our study overlaps with previous studies in general terms. It was observed in the study that emphasizing the inclusive education in the context of individual difference and creating an awareness of inclusive education indirectly influenced the attitudes of teacher candidates to a great extent.

It is reported in a study of Pürsün and Efilti (2017) involving teachers that they find it necessary to use 
differentiated instructional practices in inclusive classes. Horzum, Bektaş (2016) suggest that adaptations according to the learning requirements in science lessons will help students to join the lesson actively and understand scientific concepts. In this context, it might be said that implementing and learning differentiated practices by themselves will help teacher candidates to implement inclusive practices successfully.

In addition to designing an appropriate program, it is essential for the success of inclusive practices that teachers have the capabilities and attitude to implement this program. Teacher is the most important component of inclusive education in the context of accepting the student with special needs and setting a learning environment that meets the requirement of all students in the classroom. Not doing the necessary preparations is reported to be the most basic problem in inclusive practices (Özgür, 2015). İlgar (2017) reports that some teacher candidates do not know how to instruct students with special needs and having a student with special needs in their classroom worries them. Thus, science laboratory lesson taught with differentiated approach in our study has prepared teacher candidates for inclusive education and created an awareness to some extent. It might be suggested that this study result might be effective in the context of implementing inclusive education in the future and contribute to the solutions of problems in inclusive education.

Literature review reveals that studies on inclusive education are rather theoretical trainings and not related to major courses. However, this study shows how to relate it to a major course by giving an example of science lessons and emphasizing the condition of students with special needs as an individual difference. In this context and according to the study results, it is considered that differentiated science laboratory lessons that emphasize individual differences and particularly inclusive students will provide a good example of using inclusive practices in science education to other researchers who will study this issue.

\section{References}

Alsheikh, N., \& Elhoweris, H. (2006). Teachers' attitudes towards inclusion. International Journal of Special Education, 21(1), 115-118.

Altıntaş, E., \& Şengül, S. (2014). Özel eğitim dersinin kaynaştırmaya yönelik tutumlar ve kazanımlar bakımından değerlendirilmesi. e-Kafkas Eğitim Araştırmaları Dergisi, 1(3).

Atkın, N. (2013). Kaynaştırma. İlköğretimde özel eğitim içinde (Ed. Hasan Avcığlu, pp. 19-64). Ankara: Nobel Akademi.

Avcı, S., \& Yüksel, A. (2014). Farklılaştırlmış ögretim: Teori ve uygulama. Ankara: Nobel Akademik Yayincilik.

Avramidis, E., \& Norwich, B. (2002). Teachers' attitudes towards integration/inclusion: A review of the literature. European Journal of Special Needs Education, 17(2), 129-147. https://doi.org/10.1080/08856250210129056

Batu, E. S. (2000). Kaynaştırma, Destek Hizmetler ve Kaynaştırmaya Hazırlık Etkinlikleri. Ankara Üniversitesi Eğitim Bilimleri Fakültesi Özel Eğitim Dergisi, 2(04). https://doi.org/10.1501/Ozlegt_0000000050

Batu, S., \& Kırcaali-İftar, G. (2016). Kaynaştırma. Ankara: Kök Yayıncılık.

Bek, H., Gülveren, H., \& Başer, A. (2009). Sınıf öğretmeni adaylarının kaynaştırma eğitimine yönelik tutumlarının incelenmesi. Uş̧ak Üniversitesi Sosyal Bilimler Dergisi, 2(2), 160-168. https://doi.org/10.12780/UUSBD51

Bender, W. N., Vail, C. O., \& Scott, K. (1995). Teachers' attitudes toward increased mainstreaming: Implementing effective instruction for students with learning disabilities. Journal of Learning Disabilities, 28(2), 87-94, 120. https://doi.org/10.1177/002221949502800203

Büyüköztürk, Ş. (2015). Data analysis Handbook for social Sciences (21st ed.). Ankara: Pegem Akademi.

Büyüköztürk, Ş., Kılıç-Çakmak, E., Akgün, Ö. E., Karadeniz, Ş., \& Demirel, F. (2016). Bilimsel araştırma yöntemleri (20. bask1). Ankara: Pegem Akademi. https://doi.org/10.14527/9789944919289

ERG (Eğitim Rerformu Girişimi). (2011). Kaynaştırma/bütünleştirme yoluyla eğitimde dünyadan ve Türkiye'den iyi örnekler. Imak ofset.

Forlin, C. (2001). Inclusion: 1dentifying potential stressors for regular class teachers. Educational Research, 43(3), 235-245. https://doi.org/10.1080/00131880110081017

Gözün, Ö., \& Yıkmış, A. (2004). Öğretmen adaylarının kaynaştırma konusunda ilgilendirilmelerinin kaynaştırmaya yönelik tutumlarının değişimindeki etkililiği. Ankara Üniversitesi Ĕgitim Bilimleri Fakültesi Özel Ĕgitim Dergisi, 5(2), 65-77. https://doi.org/10.1501/Ozlegt_0000000081 
Horzum, M. B., \& Bektaş, M. (2016). Fen Bilgisi, Sosyal Bilgiler ve Geçişler. Kaynaştırma Sınıfı Etkili Farklılaştırılmış Öğretim İçin Stratejiler - Nobel Akademi Yayıncılık.

Kargın, T. (2004). Kaynaştırma: Tanımı, gelişimi ve ilkeleri. Ankara Üniversitesi Eğitim Bilimleri Fakültesi Özel Eğitim Dergisi, 5(2), 1-13. https://doi.org/10.1501/Ozlegt_0000000080

Kırcaali-İftar, G. (1998). Kaynaştırma ve destek özel eğitim hizmetleri. In S. Eripek (Ed.), Özel Ĕğitim (pp. 17-22). Eskişehir: Anadolu Üniversitesi Yayın.

MEB. (2015). Kaynaştırma yoluyla eğitim uygulamaları. Özel eğitim ve rehberlik hizmetleri genel müdürlüğü. Retrieved from http://orgm.meb.gov.tr/meb_iys_dosyalar/2015_07/24014806_kaynastirma1.sra.pdf

MEB. (2017). Genelge. Özel eğitim ve rehberlik hizmetleri genel müdürlüğü. Retrieved from http://orgm.meb.gov.tr/meb_iys_dosyalar/2017_09/21112929_kaynastirma_genelge.pdf

Mertoğlu, H., \& Topçu, M. S. (2020). Preservıce prımary school teachers'sentıments, attıtudes and concerns about inclusive education: differentiated science experıments. European Journal of Education Studies, $6(12)$.

Miles, M. B., \& Huberman A. M. (1994). Qualitative data analysis: A sourcebook of new methods. Newbury Park, CA: Sage.

Okçu, B., \& Zorluoğlu, L. (2019). Fen bilimleri eğitiminin ülkemizde tarihsel gelişimi. In M. Hüseyin \& L. Z. Seraceddin (Eds.), Çiğdem Akkanat içinde Özel eğitimde Fen ve Sosyal Bilgiler Öğretimi. Ankara: Nobel Akademi.

Orel A., Zerey, Z., \& Töret, G. (2004). Sınıf Öğretmeni Adaylarının Kaynaştırmaya Yönelik Tutumlarının İncelenmesi. Ankara Üniversitesi Ĕ̈itim Bilimleri Fakültesi Özel Ĕgitim Dergisi, 5(1), 23-33.

Özgür, İ. (2015). İlk ve ortä̈ğretimde kaynaştırma uygulamaları. Karahan Kitabevi.

Özmen, E. R. (2012). Öğretim ilkeleri ve Öğretimsel uyarlamalar. Iç̧inde Temel eğitim Öğretmenleri İçin Kaynaştırma Uygulamaları ve Özel Ĕ̈itim (5. Baskı, Ed. Ayşegül Ataman). Ankara: Vize Yayıncılık.

Pürsün, A. G. T., \& Efilti, E. (2017). Kaynaştırma sınıflarında çoklu zeka ve farklılaştırılmış öğretim uygulamalarının kullanımına ilişkin öğretmen görüşlerinin değerlendirilmesi. Eğitim ve Öğretim Araştırmaları Dergisi. Journal of Research in Education and Teaching, 6(1). ISSN: 2146-9199.

Salar, R., \& Turgut, Ü. (2019). Farklılaştırılmış Öğretimin Sınıf İklimine Etkisi: Nitel Bir Çalışma. Cumhuriyet Uluslararası Eğitim Dergisi, 8(4), 1048-1068.

Sharma, U., Forlin, C., \& Loreman, T. (2007) An international comparison of pre-service teacher attitudes towards inclusive education. Disability Studies Quarterly, 27(4). https://doi.org/10.18061/dsq.v27i4.53

Sucuoğlu, B. (2004). Türkiye'de Kaynaştırma Uygulamaları: Yayınlar/Araştırmalar. Ankara Üniversitesi Ĕgitim Bilimleri Fakültesi Özel Eğitim Dergisi, 5(02).

Tomlinson, C. A. (2001). How to differentiate instruction in mixed-ability classrooms. ABD: Association for Supervision and Curriculum Development.

Yabaş, D., \& Altun, S. (2009). The effects of differentiated instructional design on students' self-efficacy beliefs, metacognitive skills and academic achievement. Hacettepe Üniversitesi Eğitim Fakültesi Dergisi, 37(37), 201-214.

Yıldırım, A., \& Şimşek, H. (2013). Nitel Araştırma Yöntemleri. Ankara: Seçkin.

Yılmaz, E., \& Melekoğlu, M. A. (2018). Kaynaştırma eğitiminin yasa ve uygulamalardaki durumunun Türkiye ve Avrupa bağlamında değerlendirilmesi. Osmangazi Journal of Educational Research, 5(1), 1-17.

\section{Copyrights}

Copyright for this article is retained by the author, with first publication rights granted to the journal.

This is an open-access article distributed under the terms and conditions of the Creative Commons Attribution license (http://creativecommons.org/licenses/by/4.0/). 